\title{
Oxidation of medium-chain acyl-CoA esters by extracts of Aspergillus niger: enzymology and characterization of intermediates by HPLC
}

\author{
M. Fátima Baltazar, F. Mark Dickinson and Colin Ratledge
}

Author for correspondence: F. Mark Dickinson. Tel: +44 1482 465280. Fax: +44 1482465458. e-mail: F.M.Dickinson@ biosci.hull.ac.uk

Department of Biological Sciences, University of Hull, Cottingham Road, Hull HU6 7RX, UK

\begin{abstract}
The activities of $\beta$-oxidation enzymes were measured in extracts of glucoseand triolein-grown cells of Aspergillus niger. Growth on triolein stimulated increased enzyme activity, especially for acyl-CoA dehydrogenase. No acyl-CoA oxidase activity was detected. HPLC analysis after incubation of triolein-grown cell extracts with decanoyl-CoA showed that $\beta$-oxidation was limited to one cycle. Octanoyl-CoA accumulated as the decanoyl-CoA was oxidized. $\beta$-Oxidation enzymes in isolated mitochondrial fractions were also studied. The results are discussed in the context of methyl ketone production by fungi.
\end{abstract}

Keywords: $\beta$-oxidation, Aspergillus niger, methyl ketones, medium-chain fatty acids

\section{INTRODUCTION}

The development (Causey \& Bartlett, 1986; Bartlett et al., 1988) and application (Watmough et al., 1989) of HPLC techniques for the separation and identification of intermediates in the $\beta$-oxidation of fatty acids has led to improved knowledge of the details of this process in mammalian mitochondria (Watmough et al., 1989), mammalian peroxisomes (Bartlett et al., 1990) and bacteria (Broadway et al., 1992). Detailed information has been obtained on the intermediates temporarily accumulating, rate-limiting step $(s)$, metabolite channelling and degree of chain shortening.

It is widely held, although not universally (Yagi et al., 1991), that methyl ketones, which are important flavour compounds in blue cheeses, are formed by fungi because of incomplete $\beta$-oxidation (possibly peroxisomal) of medium-chain fatty acids (Lawrence \& Hawke, 1968). The oxidation is supposed to stop with the formation of 3-ketoacyl-CoA esters. Deacylation is then followed by decarboxylation, either spontaneously or under the influence of a decarboxylase. The process has been studied by many workers over the past 70 years but the above hypothesis has never been proved. Questions such as which compartment of the cell is involved or why the oxidation aborts in the first cycle of oxidation have not been answered.

Abbreviations: ABTS, 2,2'-azino-bis(3-ethylbenzthiazoline-6-sulphonic acid); DCPIP, 2,6-dichlorophenolindophenol; DTNB, 5,5'-dithiobis-(2nitrobenzoic acid); DTP, 4,4'-dithiodipyridine; PMS, phenazine methosulphate; triolein, 1,2,3-trioctadecanoylglycerol; YEPD, yeast extract/ peptone/glucose.
Kunau and co-workers (Kionka \& Kunau, 1985; Thieringer \& Kunau, 1991; Kunau et al., 1988) have provided much detailed enzymological data on peroxisomal $\beta$-oxidation in fungi, particularly Neurospora crassa. It seemed to us there was an opportunity to apply this type of enzymological work and HPLC techniques (Bartlett et al., 1988) for identifying the intermediates formed during methyl ketone production in fungi. This work is described here.

\section{METHODS}

Growth of the micro-organism. Aspergillus niger $\mathrm{N} 423$ (cpsA1 nicA1) was grown routinely in Pontecorvo complex medium (Pontecorvo et al., 1953) with the modification that $\mathrm{KH}_{2} \mathrm{PO}_{4}$ concentration was increased $10-$ fold. Growth was achieved by inoculating $200 \mathrm{ml}$ medium (in 1 litre conical flasks), containing a suitable carbon source and urea $(10 \mathrm{mM})$, with $1 \times 10^{9}$ spores. For isolation of mitochondria, growth was achieved by inoculating $200 \mathrm{ml}$ yeast extract/peptone/glucose (YEPD) in 1 litre conical flasks, containing a suitable carbon source, with $1 \times 10^{9}$ conidia. YEPD contained (per litre): proteose peptone, $20 \mathrm{~g}$; yeast extract, $10 \mathrm{~g}$; glucose, $20 \mathrm{~g}$; Pontecorvo vitamin solution, $10 \mathrm{ml}$. Cultures were incubated on an orbital shaker ( 145 r.p.m.) at $30^{\circ} \mathrm{C}$. Solid cultivation and maintenance were performed on potato/dextrose agar $\left(39 \mathrm{~g} \mathrm{l}^{-1}\right)$.

Spores were obtained after growth on potato/dextrose agar at $30^{\circ} \mathrm{C}$ for $3-4 \mathrm{~d}$ or until sporulation. Spores were harvested by gentle suspension in a sterile solution of Tween $80(0.8 \%$, $\mathrm{w} / \mathrm{v}$ ) and subsequent filtration through glass-wool. Spore suspensions were stored at $-20^{\circ} \mathrm{C}$ in portions (up to $1.5 \mathrm{ml}$ ) containing $1 \times 10^{9}$ spores. The stock was renewed every $2-3$ months. 
Transference of mycelia. As the growth on certain carbon sources such as fatty acid methyl esters and triacylglycerols (especially the ones containing medium-chain fatty acids) was poor, the behaviour of $A$. niger after incubation with these substrates was studied by transference: after the first incubation, the mycelia were harvested by filtration through a pre-sterilized filter (Miracloth, Calbiochem), washed thoroughly with sterile distilled water and transferred aseptically to a second medium containing fatty acid, methyl ester, triacylglycerol, etc., before incubation for the required period.

Harvesting of mycelia and preparation of cell-free extracts. Mycelia were harvested at room temperature by vacuum filtration through Whatman no.1 filter paper and washed thoroughly with distilled water. The resultant cell cake was weighed (wet weight) and used for preparation of cell-free extracts, or stored at $-20^{\circ} \mathrm{C}$. Cell-free extracts were obtained by passing the cell-suspension $(1 \mathrm{~g}$ cell cake per $15 \mathrm{ml} 50 \mathrm{mM}$ HEPES pH 7.5 containing $1 \mathrm{mM}$ DTT) three times through a pre-cooled French pressure cell $(35 \mathrm{MPa})$. (For some experiments studying methyl ketone production cell walls were weakened with $1 \%$ Caylase $\mathrm{C}_{3}$ and $0.25 \%$ cellulase at $\mathrm{pH} 5.5$ and $37^{\circ} \mathrm{C}$ before passage through the French pressure cell.) The fungal homogenate was centrifuged at $7700 \mathrm{~g}$ for $10 \mathrm{~min}$ at $4{ }^{\circ} \mathrm{C}$ to remove whole cells and cell debris. The supernatant was taken as cell-free extract and was either used immediately or stored in small aliquots $(1.5 \mathrm{ml})$ in liquid nitrogen until required.

Enzyme assays. All enzyme assays were carried out at $30^{\circ} \mathrm{C}$ in a Unicam 8625 UV/VIS spectrophotometer.

Acyl-COA dehydrogenase (EC 1.3.99.3). The reaction mixture included the following components (final volume $1 \mathrm{ml}$ ): $0 \cdot 15 \mathrm{M}$ HEPES pH 8.0,0.6 ml; $1 \mathrm{mM}$ DCPIP, $0 \cdot 1 \mathrm{ml} ; 1 \mathrm{mM}$ PMS, $0.05 \mathrm{ml} ; 2 \mathrm{mM}$ acyl-CoA, $0.05 \mathrm{ml}$; water and enzyme preparation, $0.2 \mathrm{ml}$. The reaction was started by acyl-CoA addition. An absorption coefficient of $21500 \mathrm{M}^{-1} \mathrm{~cm}^{-1}$ was used for DCPIP at $\mathrm{pH} 8 \cdot 0$. The assay follows the decrease in absorbance at $600 \mathrm{~nm}$ due to DCPIP reduction.

Acyl-COA oxidase (EC 1.3.3.6). The reaction mixture included (final volume $1 \mathrm{ml}$ ): $100 \mathrm{mM}$ HEPES $\mathrm{pH} 7 \cdot 5,0.8 \mathrm{ml} ; 25 \mathrm{mM}$ ABTS, $0.05 \mathrm{ml} ; 1 \mathrm{mg} \mathrm{ml}^{-1}$ peroxidase, $0.05 \mathrm{ml} ; 2.1 \mathrm{mM}$ acylCoA, $0.05 \mathrm{ml}$; enzyme preparation, $0.05 \mathrm{ml}$. The reaction was started by acyl-CoA addition. The absorption coefficient for the ABTS radical cation is $18400 \mathrm{M}^{-1} \mathrm{~cm}^{-1}$. The increase in absorbance at $405 \mathrm{~nm}$ due to ABTS reduction was followed (Werner et al., 1970).

Enoyl-CoA hydratase (crotonase; EC 4 2 2 1 . 17), L-3-hydroxyacyl-CoA dehydrogenase (EC 1.1.1.35) and 3-ketoacyl-COA thiolase (EC 3.1.2.20). These enzymes were assayed according to Binstock \& Schulz (1981).

Acyl-CoA hydrolase (EC 3 1 1.2.11). This assay is based on that of Ramsay \& Tubbs (1975) for carnitine acetyltransferase. The assay mixture contained: $50 \mathrm{mM}$ HEPES pH 7.5, $0.5 \mathrm{ml}$; water, $0.3 \mathrm{ml} ; 1.2 \mathrm{mM}$ DTP, $0.1 \mathrm{ml} ; 2.1 \mathrm{mM}$ acyl-CoA, $0.05 \mathrm{ml}$; enzyme preparation, $0.05 \mathrm{ml}$. The reaction was started by acyl-CoA addition. An absorption coefficient of $19800 \mathrm{M}^{-1} \mathrm{~cm}^{-1}$ for DTP was used to calculate rates. The increase in absorbance at $324 \mathrm{~nm}$ due to reduction of DTP was followed.

Acyl-COA synthetase (EC 6.2.1.3). The assay was undertaken in two steps: first the formation of the acyl-CoA ester by acylCoA synthetase, and second the detection of the amount of CoASH consumed, by reaction with ABTS. The first step of the assay was based on the assay for acyl-CoA synthetase of Ichihara \& Shibasaki (1991) and contained (in a final volume of $0.5 \mathrm{ml}$ ) : $0.43 \mathrm{M}$ MOPS/NaOH buffer $\mathrm{pH} 7 \cdot 6,0.175 \mathrm{ml}$;
$13.75 \mathrm{mM}$ Triton X-100, $0.02 \mathrm{ml} ; 12.5 \mathrm{mM}$ CoASH, $0.02 \mathrm{ml}$; $45 \mathrm{mM}$ ATP, $0.05 \mathrm{ml} ; 0.3 \mathrm{M} \mathrm{MgCl}_{2}, 0.02 \mathrm{ml}$; cell-free extract and water, $0.145 \mathrm{ml} ; 12.5 \mathrm{mM}$ potassium oleate (substrate), $0.02 \mathrm{ml}$. An aliquot of the previous assay $(60 \mu \mathrm{l})$ was withdrawn and added to the following mixture: $50 \mathrm{mM}$ sodium phosphate buffer $\mathrm{pH} 6.5,2.6 \mathrm{ml} ; 25 \mathrm{mM}$ ABTS, $0.15 \mathrm{ml} ; 1 \mathrm{mg}$ peroxidase $\mathrm{ml}^{-1}, 0 \cdot 15 \mathrm{ml} ; 1 \mathrm{mM} \mathrm{H}_{2} \mathrm{O}_{2}, 0.05 \mathrm{ml}$. The decrease in absorbance at $405 \mathrm{~nm}$ due to free CoASH present in the assay was measured and subtracted from a blank in which the substrate was omitted. An absorption coefficient of $18400 \mathrm{M}^{-1}$ $\mathrm{cm}^{-1}$ for ABTS radical cation was used.

$\beta$-Oxidation indirect assay. In this assay, acyl-CoA esters are generated in situ by the acyl-CoA synthetases already present in the extract. The assay contained (final volume $1 \mathrm{ml}$ ): $0 \cdot 5 \mathrm{M}$ HEPES buffer $\mathrm{pH} 8 \cdot 0,0.5 \mathrm{ml} ; 40 \mathrm{mM} \mathrm{Na}_{2}$ ATP, $0.1 \mathrm{ml} ; 40 \mathrm{mM}$ $\mathrm{MgCl}_{2} \cdot 6 \mathrm{H}_{2} \mathrm{O}, 0 \cdot 1 \mathrm{ml} ; 17 \mathrm{mM} \mathrm{NAD}{ }^{+}, 0 \cdot 1 \mathrm{ml} ; 6 \mathrm{mM} \mathrm{CoASH}$, $0.1 \mathrm{ml}$; cell-free extract and fatty acid $(0.68 \mu \mathrm{mol}$, added in $7 \mu \mathrm{l}$ DMSO). The reaction was initiated by substrate addition and activity was measured by following the increase in absorbance at $340 \mathrm{~nm}$ due to $\operatorname{NAD}^{+}$reduction $\left(\varepsilon_{340}=6220 \mathrm{M}^{-1} \mathrm{~cm}^{-1}\right)$.

$\beta$-Oxidation direct assay. The assay contained (final volume $1 \mathrm{ml}): 150 \mathrm{mM}$ HEPES buffer $\mathrm{pH} 8.0,0.6 \mathrm{ml} ; 17 \mathrm{mM} \mathrm{NAD}^{+}$, $0.1 \mathrm{ml} ; 6 \mathrm{mM}$ CoASH, $0.05 \mathrm{ml}$; cell-free extract and acyl-CoA ester $(100 \mathrm{nmol}$ introduced in the assay as an aqueous solution). The reaction was started by acyl-CoA addition and activity was measured by following $\mathrm{NAD}^{+}$reduction at $340 \mathrm{~nm}$. All incubation mixtures contained between $0 \cdot 1$ and $0.15 \mathrm{mg}$ of protein. NADH formation was routinely checked by addition of yeast alcohol dehydrogenase $(30 \mu \mathrm{g})$ and acetaldehyde $(0.5 \mu \mathrm{mol})$ to the assay mixture. The resulting decrease in absorbance at $340 \mathrm{~nm}$ (NADH oxidation) corresponded to the NADH formed in the assay.

Acetyl-CoA estimation. Acetyl-CoA was assayed using citrate synthase and oxaloacetate. CoASH released on condensation of acetyl-CoA and oxaloacetate was measured by reaction with DTNB. An aliquot of reaction mixture $(200 \mu \mathrm{l})$ was added to trichloroacetic acid $(60 \mu \mathrm{l}, 15 \%, \mathrm{w} / \mathrm{v})$ and precipitated protein was removed by centrifugation ( $5 \mathrm{~min}$ ). Then $200 \mu$ of the supernatant was added to $0.8 \mathrm{M} \mathrm{Tris} / \mathrm{HCl}$ buffer $\mathrm{pH} 8.0(0.8 \mathrm{ml})$ containing oxaloacetate (approx. $2 \mathrm{mg}$ solid) and DTNB (250 nmol) and the absorbance at $412 \mathrm{~nm}$ $\left(A_{1}\right)$ was read against a blank assay (without substrate). Citrate synthase (pigeon breast muscle, $1 \mathrm{U}$ ) was added to the mixture and the increased absorbance at $412 \mathrm{~nm}\left(\mathrm{~A}_{2}\right)$ measured. The amount of acetyl-CoA was given by the difference $\mathrm{A}_{2}-\mathrm{A}_{1}$ due to the release of CoASH from acetyl-CoA and subsequent reaction with DTNB. An absorption coefficient of $13600 \mathrm{M}^{-1} \mathrm{~cm}^{-1}$ for DTNB was used.

Carnitine acyltransferase (EC 2.3.1.7). This assay is based on that of Ramsay \& Tubbs (1975) for carnitine acetyltransferase using L-carnitine. The reaction mixture contained (final volume $1 \mathrm{ml}$ ): $250 \mathrm{mM}$ sodium phosphate buffer $\mathrm{pH} 7 \cdot 8$, $0.1 \mathrm{ml} ; 0.3 \mathrm{mM}$ acyl-CoA, $0.3 \mathrm{ml} ; 1.2 \mathrm{mM}$ DTP, $0.1 \mathrm{ml} ; 1 \mathrm{M}$ $\mathrm{KCl}, 0.1 \mathrm{ml}$; water and enzyme preparation, $0.35 \mathrm{ml} ; 40 \mathrm{mM}$ $\mathrm{L}$-carnitine, $0.05 \mathrm{ml}$. The reaction was started by L-carnitine addition and an absorption coefficient of $19800 \mathrm{M}^{-1} \mathrm{~cm}^{-1}$ was used to calculate rates. The increase in absorbance at $324 \mathrm{~nm}$, due to reduction of dithiobispyridine (DTP), was followed.

Citrate synthase (EC 4.1.3.7). The method follows the increase in absorbance at $412 \mathrm{~nm}$ due to mercaptide formation, resulting from the reaction between DTNB and CoASH (Parvin, 1969). The reaction volume contained (final volume $1 \mathrm{ml}$ ) : $0.5 \mathrm{M}$ Tris $/ \mathrm{HCl} \mathrm{pH} 8 \cdot 0,0.2 \mathrm{ml} ; 1 \mathrm{mM}$ oxaloacetate, (freshly prepared in $100 \mathrm{mM}$ Tris $/ \mathrm{HCl} \mathrm{pH} \mathrm{8.0),0.1} \mathrm{ml;} 1 \mathrm{mM}$ acetyl-CoA, $0 \cdot 1 \mathrm{ml} ; 5 \mathrm{mM}$ DTNB (prepared in $100 \mathrm{mM}$ 
Tris $/ \mathrm{HCl} \mathrm{pH} \mathrm{8.0)0.05} \mathrm{ml}$ and water. The reaction was started with enzyme addition. The molar absorption coefficient for DTNB was $13600 \mathrm{M}^{-1} \mathrm{~cm}^{-1}$.

Protein content. Protein was estimated by the method of Bradford (1976), using BSA as a standard.

\section{Synthesis of acyl-CoA esters}

Enoyl-CoA esters. Enoyl-CoA esters were synthesized from the saturated acyl-CoA esters by acyl-CoA oxidase. The mixture contained (final volume $1 \mathrm{ml}$ ) $: 0 \cdot 2 \mathrm{M}$ sodium phosphate buffer $\mathrm{pH} 6.5,0.75 \mathrm{ml} ; 5 \mathrm{U}$ acyl-CoA oxidase $\mathrm{ml}^{-1}, 0.05 \mathrm{ml} ; 2 \mathrm{mM}$ acyl-CoA ester, $0.05 \mathrm{ml}$; the reaction was started by acyl-CoA addition.

3-Hydroxyacyl-CoA esters. 3-Hydroxyacyl-CoA esters were synthesized from the saturated acyl-CoA esters by acyl-CoA oxidase and enoyl-CoA hydratase. The reaction was undertaken in two steps: first the formation of the enoyl-CoA, and second the hydration of the enoyl-CoA double bond followed at $263 \mathrm{~nm}$. The reaction mixture contained (final volume $1 \mathrm{ml}): 0.2 \mathrm{M}$ sodium phosphate buffer $\mathrm{pH} 6.5,0.75 \mathrm{ml} ; 5 \mathrm{U}$ acyl-CoA oxidase $\mathrm{ml}^{-1}, 0.05 \mathrm{ml}$; $5 \mathrm{U}$ enoyl-CoA hydratase $\mathrm{ml}^{-1}, 0.005 \mathrm{ml} ; 2 \mathrm{mM}$ acyl-CoA ester, $0.05 \mathrm{ml}$. The reaction was started by acyl-CoA addition.

$\beta$-Ketoacyl-CoA esters. $\beta$-Ketoacyl-CoA esters were formed from the corresponding saturated acyl-CoA esters by the combined action of acyl-CoA oxidase, enoyl-CoA hydratase and L-3hydroxyacyl-CoA dehydrogenase. This synthesis is based on the assay of thiolase described by Seubert et al. (1968). The assay follows the increase in absorbance at $303 \mathrm{~nm}$ due to the formation of the enol form of the $\beta$-ketoacyl-CoA ester. The assay mixture contained (final volume $1.025 \mathrm{ml}$ ): $133 \mathrm{mM}$ Tris/ $\mathrm{HCl}$ buffer $\mathrm{pH} 8.9,0.75 \mathrm{ml} ; 0.2 \mathrm{M} \mathrm{MgSO}_{4}, 0.025 \mathrm{ml}$; $10 \mathrm{mg} \mathrm{ml}^{-1} \mathrm{BSA}, 0.05 \mathrm{ml} ; 40 \mathrm{mM}$ sodium pyruvate, $0.025 \mathrm{ml}$; $20 \mathrm{mM} \mathrm{NAD}{ }^{+}, 0.025 \mathrm{ml} ; 2 \mathrm{mM}$ acyl-CoA ester, $0.05 \mathrm{ml} ; 970 \mathrm{U}$ lactate dehydrogenase $\mathrm{ml}^{-1}, 0.005 \mathrm{ml} ; 5 \mathrm{U}$ acyl-CoA oxidase $\mathrm{ml}^{-1}, 0.045 \mathrm{ml} ; 5 \mathrm{U}$ enoyl-CoA hydratase $\mathrm{ml}^{-1}, 0.005 \mathrm{ml}$ (freshly diluted from a $50 \mathrm{U} \mathrm{ml}^{-1}$ solution); $10 \mathrm{U} \mathrm{L-3-}$ hydroxyacyl-CoA dehydrogenase $\mathrm{ml}^{-1}, 0.045 \mathrm{ml}$. The reaction was started by the addition of the acyl-CoA ester.

Extraction and analysis of acyl-CoA esters by HPLC. Acyl-CoA esters were extracted from $\beta$-oxidation reaction mixtures as described by Causey \& Bartlett (1986) with minor modifications. An aliquot $(0.5 \mathrm{ml})$ taken from a $\beta$-oxidation assay was quenched by the addition of glacial acetic acid $(100 \mu \mathrm{l})$. An internal standard (acyl-CoA ester, $50 \mathrm{nmol}$ ) was added and the mixture extracted three times with a total of $15 \mathrm{ml}$ diethyl ether to remove fatty acids. Saturated $\left(\mathrm{NH}_{4}\right)_{2} \mathrm{SO}_{4}$ $(50 \mu \mathrm{l})$ was added to the aqueous phase and a mixture of methanol/chloroform $(2: 1, \mathrm{v} / \mathrm{v}, 3 \mathrm{ml})$ added slowly. The mixture was kept for $20 \mathrm{~min}$ at room temperature. The salt/protein precipitate was then removed by centrifugation $(1000 \mathrm{~g}, 5 \mathrm{~min})$ and the supernatant separated. The resultant pellet was extracted with a further $3 \mathrm{ml}$ methanol/chloroform $(2: 1, v / v)$ and the supernatants combined. The solvent was removed by evaporation under a gentle stream of $\mathrm{N}_{2}$ at $55^{\circ} \mathrm{C}$. The residue was resuspended in $200 \mu \mathrm{KH}_{2} \mathrm{PO}_{4}(50 \mathrm{mM}, \mathrm{pH}$ 5.3) and $20 \mu$ lanalysed by HPLC.

HPLC was carried out with a system equipped with a Kontron 420 HPLC pump and a Kontron 425 HPLC gradient former using a Lichrosorb $10 \mathrm{RP} 18$ column $(250 \mathrm{~mm} \times 4.6 \mathrm{~mm})$ at room temperature. Column eluates were monitored by using a Kontron 432 HPLC detector at $260 \mathrm{~nm}$. Peak areas were determined by a Kontron I-459 integrator. Acyl-CoA esters were resolved by the following gradient of acetonitrile in $50 \mathrm{mM} \mathrm{KH}_{2} \mathrm{PO}_{4}(\mathrm{pH} 5 \cdot 3)$ : isocratic $5 \%(\mathrm{v} / \mathrm{v})$ for $5 \mathrm{~min}$, linear to $40 \%(\mathrm{v} / \mathrm{v})$ for $10 \mathrm{~min}$, linear to $50 \%(\mathrm{v} / \mathrm{v})$ for $5 \mathrm{~min}$. The flow rate was $1 \mathrm{ml} \mathrm{min}^{-1}$ throughout and all solvents were continuously de-aerated with helium.

Extraction and determination of methyl ketones, secondary alcohols and fatty acids. After harvesting the mycelia, the $\mathrm{pH}$ of the spent medium was adjusted to 1-2 with $\mathrm{H}_{2} \mathrm{SO}_{4}$ and internal standards were added (methyl ketone and fatty acid). The medium was then extracted twice with chloroform $(2 \times$ half the volume of medium) and the chloroform layers collected and combined. The residual water was removed with anhydrous $\mathrm{MgSO}_{4}$ and the solvent reduced down to a convenient volume by rotary evaporation.

Methyl ketones, secondary alcohols and fatty acids were analysed by using a PYE Unicam PU 4500 chromatograph, equipped with an integrator and a flame ionization detector, fed with hydrogen $\left(44 \mathrm{ml} \mathrm{min}{ }^{-1}\right)$ and air $\left(600 \mathrm{ml} \mathrm{min}^{-1}\right)$. The apparatus was fitted with a $10 \%(\mathrm{w} / \mathrm{v})$ DEGS (diethylene glycol succinate) packed column $(130 \mathrm{~cm} \times 4 \mathrm{~mm})$, using

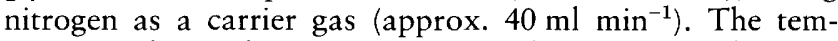
perature of the column was maintained at $130{ }^{\circ} \mathrm{C}$, and that of the injector and detector at $160^{\circ} \mathrm{C}$. Compounds were quantified by automatic integration.

Electron microscopy of mycelia. The method used for the preparation of cells for electron microscopy was that of Graves et al. (1976), slightly modified: after embedding, $4 \%$ $(\mathrm{w} / \mathrm{v}$ ) glutaraldehyde in $0.1 \mathrm{M}$ cacodylate buffer $\mathrm{pH} 7.5$ was used and fixation was in $1 \%(\mathrm{w} / \mathrm{v}) \mathrm{OsO}_{4}$.

Isolation of mitochondria. After harvesting and washing, the mycelia (6 g wet weight) were ground gently with washed sand ( $2 \mathrm{~g}$ per $\mathrm{g}$ mycelia) in $50 \mathrm{mM}$ sodium phosphate buffer $\mathrm{pH} 7.0$ containing $5 \mathrm{mM}$ EDTA, $0.6 \mathrm{M}$ sucrose and $0.3 \%$ $(\mathrm{w} / \mathrm{v})$ BSA $(6 \mathrm{ml})$ [isolation buffer (Mannella, 1982)], in a precooled pestle and mortar $(3-4 \mathrm{~min})$. The resultant paste was suspended in an additional $34 \mathrm{ml}$ of the same buffer solution and PMSF $(0.5 \mathrm{mM}$ final concentration) added to the mixture. The homogenate was centrifuged at $1000 \mathrm{~g}$ for $10 \mathrm{~min}$, the pellet was discarded, and the supernatant was filtered through two layers of muslin and centrifuged at $16000 \mathrm{~g}$ for $10 \mathrm{~min}$. The resultant pellet was taken as the crude mitochondrial fraction; this was gently taken up in isolation buffer, washed once and resuspended. For further purification, the crude mitochondrial pellet was suspended in isolation buffer containing $25 \%(\mathrm{v} / \mathrm{v})$ Percoll and centrifuged at $48000 \mathrm{~g}$ for $1 \mathrm{~h}$. After centrifugation, the gradient was displaced with a $2 \mathrm{M}$ sucrose solution. Fractions $(1 \mathrm{ml})$ were collected from the top of the gradient.

Respiration measurements on mitochondria. The respiratory activity of the mitochondrial preparations was measured by the use of a Clark-type $\mathrm{O}_{2}$ electrode (Rank Bros). The experiments were conducted at $30^{\circ} \mathrm{C}$ and assays contained (in a final volume of $3 \mathrm{ml}$ ): $10 \mathrm{mM}$ sodium succinate, $0.3 \mathrm{mM}$ ADP, mitochondrial preparation and Lambowitz buffer ( $8 \mathrm{mM} \mathrm{NaH}_{2} \mathrm{PO}_{4}, 8 \mathrm{mM}$ Tris, $5 \mathrm{mM} \mathrm{MgCl}_{2}, 0.7 \mathrm{mM}$ EDTA, $0.3 \mathrm{M}$ sucrose, $\mathrm{pH} 7 \cdot 2$ ) (Lambowitz et al., 1972). Mitochondrial suspensions were disrupted on ice by sonication $(3 \times 20 \mathrm{~s})$, prior to enzyme assays.

Chemicals. Saturated acyl-CoA esters (except acetyl-CoA), fatty acids, fatty acid methyl esters, medium-chain triacylglycerols, triolein (practical grade), acyl-CoA oxidase (from Candida sp.), acyl-CoA synthetase (from E. coli), crotonase, 3hydroxyacyl-CoA dehydrogenase (type V), peroxidase (type I, from horseradish), citrate synthase (from pigeon breast muscle) and Percoll were purchased from Sigma. Alcohol dehydrogenase (EC 1.1.1.1, from yeast) and cellulase were 
from Boehringer Mannheim. Caylase $\mathrm{C}_{3}$ was from Cayla (Toulouse, France). DMSO was obtained from Fisons Scientific Apparatus. Authentic methylalkyl ketones and their respective secondary alcohols were obtained from Aldrich. Yeast extract, proteose peptone and potato/dextrose agar were from Oxoid. Acetyl-CoA was synthesized according to Simon \& Shemin (1953).

\section{RESULTS}

\section{Selection of micro-organism}

Aspergillus niger was selected for this work. It showed rapid growth on glucose and on triolein and proved a good producer of methyl ketones, especially 2heptanone and 2-nonanone. These findings confirm those of Yagi et al. (1990).

\section{Methyl ketone production by cells and cell extracts}

Fig. 1 shows the time course for the formation of decanoic acid and 2-nonanone on presenting trioleingrown $A$. niger with $0.5 \%$ (w/v) methyl decanoate. There appeared to be a slight lag in 2-nonanone production, but since the appearance of this product was likely to be consequent upon the liberation of decanoic acid from methyl decanoate by cellular lipase(s) this was not surprising. There was also the possibility that residual triolein or oleic acid associated with the cells interfered in the processing of decanoic acid. It was always very difficult to remove triolein from cells prior to transfer to a second medium. In an experiment using 1,2,3-tridecanoylglycerol as the substrate for 2-nonanone production, similar results were obtained, but now about $35 \mathrm{~h}$ was required to generate the levels of product seen at $4 \mathrm{~h}$ in Fig. 1. Presumably, the lipase(s) involved were much less active with 1,2,3tridecanoylglycerol.

Incubation of glucose-grown $A$. niger with $0.5 \%(\mathrm{w} / \mathrm{v})$ 1,2,3-tridecanoylglycerol for $16 \mathrm{~h}$ resulted in complete

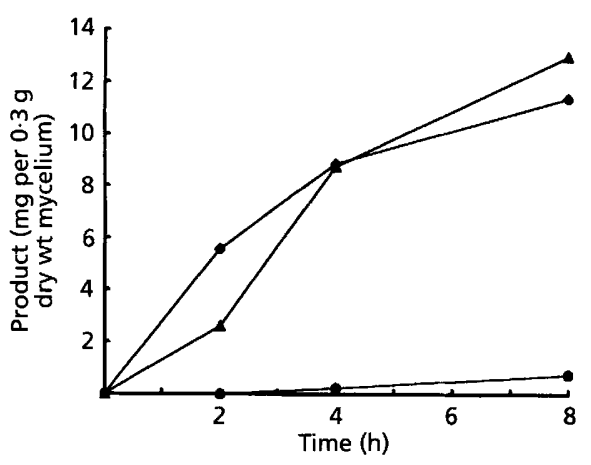

\footnotetext{
Fig. 1. Production of 2 -nonanone by $A$. niger triolein-grown mycelia on incubation with methyl decanoate. Mycelia were first grown on triolein $(0.5 \%, w / v)$ for $40 \mathrm{~h}$ and then transferred to a second incubation medium (Pontecorvo complex medium, $200 \mathrm{ml}$ ) containing $0.5 \%(w / v)$ methyl decanoate. $\Delta, 2-$ Nonanone; O, 2-nonanol; $\bullet$, decanoic acid. Data are the means of duplicate experiments.
}

loss of cell viability and only about $30 \%$ of the initial cell mass could be recovered. The same effect was seen with $4 \mathrm{mM}$ decanoic acid, suggesting that the effect with 1,2,3-tridecanoylglycerol was due to the release and accumulation of decanoic acid. Electron microscope examination of the cell residue showed no sign of mitochondria, peroxisomes, etc., and the cell walls were often ruptured. As the incubations produced some 2nonanone initially, much as did the triolein-grown cells, it was tempting to suggest that methyl ketone production was somehow linked to those degradative effects. However, in experiments with cells pre-grown on triolein then incubated with $0.5 \%(\mathrm{w} / \mathrm{v})$ methyl decanoate or 1,2,3-tridecanoylglycerol over $16 \mathrm{~h}$ the cells remained viable, showed no signs of damage in the electron microscope and, as shown in Fig. 1, produced 2nonanone. It is not known why triolein-grown cells were more robust towards decanoic acid. Perhaps it was because these cells had a much enhanced $\beta$-oxidation activity (see below).

Incubations of extracts from triolein-grown cells with octanoic or decanoic acids (1 mM) and ATP (1-10 mM) and $\mathrm{MgCl}_{2}(1-10 \mathrm{mM})$, or of the cell extracts with decanoyl-CoA $(0.1 \mathrm{mM})$, yielded no measurable quantities of 2-heptanone or 2-nonanone over a $12 \mathrm{~h}$ period. Extracts of cells which, prior to cell breakage, had been producing 2-heptanone from octanoic acid, also failed to form 2-heptanone. After $24 \mathrm{~h}$, some 2heptanone was produced from octanoic acid, but in these cases, it was always possible to demonstrate the presence of mycelia. When cycloheximide $\left(1 \mathrm{mg} \mathrm{ml}^{-1}\right)$ was included in the $24 \mathrm{~h}$ incubations, no 2-heptanone could be found.

Our results do not support the findings of Yagi et al. (1991), who reported the formation of 2-nonanone from the oxidation of decanoic acid by a cell-free system from Penicillium decumbens. We did find, as did Yagi et al. (1991), that cell extracts could be apparently separated into a heat-labile pellet $(3000 \mathrm{~g})$ and heat-stable supernatant fraction $(3000 \mathrm{~g})$ which when combined together generated 2-heptanone from octanoic acid. Also, we found that methyl ketone formation was stimulated (six- to sevenfold) by $1-3 \mathrm{mM} \mathrm{Ca}{ }^{2+}\left(\mathrm{CaCl}_{2}\right)$. However, our incubations required $24 \mathrm{~h}$ and not $4 \mathrm{~h}$ to generate 2 heptanone, and mycelia could always be detected.

\section{Activities of $\beta$-oxidation enzymes}

The activities of the enzymes of $\beta$-oxidation found in glucose- and triolein-grown $A$. niger are shown in Table 1. Some of the enzymes, but particularly acyl-CoA dehydrogenase, were induced by triolein. With triolein, the activities of the enzymes were very similar to those seen for Neurospora crassa (Kionka \& Kunau, 1985) and Candida tropicalis (Dommes et al., 1983) after contact with oleic acid. This was a little surprising in view of the differences in substrate and assay conditions used, but it may be that these enzymes are rather insensitive to these changes. As with $N$. crassa (Kionka $\&$ Kunau, 1985) there was no trace of acyl-CoA oxidase 
Table 1. $\beta$-Oxidation enzyme activities in $A$. niger under two different growth conditions

Mycelia were grown either on glucose $(50 \mathrm{mM})$ or triolein $(0.5 \%, \mathrm{w} / \mathrm{v})$, for 24 and $40 \mathrm{~h}$, respectively. Values of activities are means \pm SD for four determinations (two replicates from two different cultures). ND, Not detected.

\begin{tabular}{|lccc|}
\hline $\begin{array}{l}\text { Enzyme activity } \\
\text { [nmol min }\end{array}$ & \multicolumn{2}{c}{ Growth substrate } & $\begin{array}{c}\text { Ratio } \\
(\text { mean })\end{array}$ \\
\cline { 2 - 3 } & Glucose & Triolein & \\
\hline Acyl-CoA oxidase & ND & ND & - \\
Acyl-CoA dehydrogenase & $<0 \cdot 2$ & $80 \pm 30$ & $>400$ \\
$\begin{array}{l}\text { Enoyl-CoA hydratase } \\
\text { 3-Hydroxyacyl-CoA } \\
\text { dehydrogenase }\end{array}$ & $700 \pm 50$ & $900 \pm 90$ & $1 \cdot 3$ \\
3-Ketoacyl-CoA thiolase & $130 \pm 15$ & $360 \pm 120$ & $2 \cdot 8$ \\
\hline
\end{tabular}

activity in A. niger; this contrasts with C. tropicalis, where a 700 -fold induction of this enzyme activity

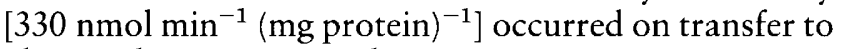
oleic acid (Dommes et al., 1983).

Activities for the $\beta$-oxidation enzymes in glucose-grown A. niger (Table 1) differed quite markedly from those of N. crassa (Kionka \& Kunau, 1985) and C. tropicalis (Dommes et al., 1983). For acyl-CoA dehydrogenase, we found barely detectable levels of activity (see below) and these were much lower ( 50 -fold) than found for the other organisms. For enoyl-CoA hydratase and 3ketoacyl-CoA thiolase, our measured activities were by contrast much higher (10- to 100-fold).

Assays of acyl-CoA dehydrogenase as performed here used PMS as electron carrier and DCPIP as electron acceptor and they were very sensitive to the presence of any free thiol (e.g. CoASH) because it rapidly reduced the electron acceptors. Accordingly, with extracts containing an active acyl-CoA thioesterase there was an 'apparent' acyl-CoA dehydrogenase activity. Extracts of glucose-grown A. niger showed an acyl-CoA thioesterase activity of $2 \mathrm{nmol} \mathrm{min}^{-1}\left(\mathrm{mg}\right.$ protein) ${ }^{-1}$. When the effect of this on acyl-CoA dehydrogenase assays was corrected for, the resulting activities were very low (Table 1$)$. Most $(\geqslant 90 \%)$ of the observed activity was due to the acyl-CoA thioesterase. This no doubt meant that our estimate for acyl-CoA dehydrogenase in glucose-grown cells was inaccurate, although clearly much more informative than an uncorrected value. Kionka \& Kunau (1985) and Dommes et al. (1983) used a different electron-acceptor system, but they did not mention acyl-CoA thioesterase or any necessary correction in discussing their data. Accordingly, it is not clear that our results for acyl-CoA dehydrogenase in glucose-grown cells can be compared. This problem does not arise with the results for triolein-grown cells of A. niger. In these extracts, the activity of the acyl-CoA thioesterase was about the same as for glucose-grown cells while the acyl-CoA dehydrogenase was 400 -fold more active.

\section{$\boldsymbol{\beta}$-Oxidation assays}

Attempts to follow the $\beta$-oxidation of decanoyl-CoA by extracts of glucose-grown cells were unsuccessful because no significant formation of $\mathrm{NADH}$ could be demonstrated. This was not surprising in view of the very low activity for acyl-CoA dehydrogenase recorded in Table 1. 'Indirect' assays using decanoic acid, ATP, $\mathrm{MgCl}_{2}, \mathrm{CoASH}$ and $\mathrm{NAD}^{+}$and extracts of trioleingrown cells were also unsuccessful. The detection of activity here was made more difficult by the very low activity of acyl-CoA synthetase $\left[25 \mathrm{nmol} \mathrm{min}^{-1}(\mathrm{mg}\right.$ protein $)^{-1}$ with decanoic acid as substrate] in these extracts.

Assays of $\beta$-oxidation with extracts of triolein-grown cells incubated with decanoyl-CoA gave rapid and continuous production of NADH on addition of substrate. The reactions were completed within $30-60 \mathrm{~min}$, by which time approximately $1 \mathrm{~mol} \mathrm{NADH}$ was produced per mol added substrate. Similar results were obtained with octanoyl-CoA. Thus, the activity was easily detected, although the overall process was limited in extent. If, by contrast, the reaction mixture which contained about $0.01 \mathrm{U}$ acyl-CoA dehydrogenase was supplemented with $0 \cdot 1 \mathrm{U}$ commercial acyl-CoA oxidase the initial rate of NADH production was increased 10to 20 -fold and after $20 \mathrm{~min}$ about $3 \mathrm{~mol} \mathrm{NADH}$ were produced per mol added substrate.

The rates of decanoyl-CoA oxidation in $\beta$-oxidation and in acyl-CoA dehydrogenase assays were compared over a range $(25-300 \mu \mathrm{M})$ of substrate concentrations at $30^{\circ} \mathrm{C}, \mathrm{pH} 8 \cdot 0$. Results were reproducible to within $\pm 10 \%$ and the Lineweaver-Burk plots were linear.

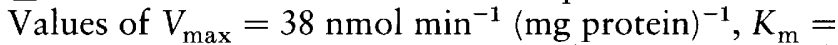
$130 \mu \mathrm{M}$, and $V_{\max }=15 \mathrm{nmol} \min ^{-1}\left(\mathrm{mg}\right.$ protein) ${ }^{-1}$, $K_{\mathrm{m}}=30 \mu \mathrm{M}$ were obtained in $\beta$-oxidation and in acylCoA dehydrogenase assays, respectively. The fact that the two assays did not agree was not surprising because, even if $\beta$-oxidation was strictly limited by acyl-CoA dehydrogenase, the electron acceptor system was quite different for the two types of assay. The nature of the 'natural' electron acceptor for acyl-CoA dehydrogenase in $\beta$-oxidation assays was uncertain, especially so if the enzyme was of microbody origin.

\section{HPLC analysis of products of $\beta$-oxidation}

Incubations of tetradecanoyl-CoA with extracts of triolein-grown $A$. niger over a $30 \mathrm{~min}$ period and analysis showed that the formation of dodecanoyl- and decanoyl-CoA could be identified as the reaction progressed. No other intermediates were found. Mixing of decanoyl-CoA with extracts of triolein-grown cells revealed a much more limited process. Only one CoA ester product could be identified over a $120 \mathrm{~min}$ period (Fig. 2) and this product accumulated as the decanoyl- 


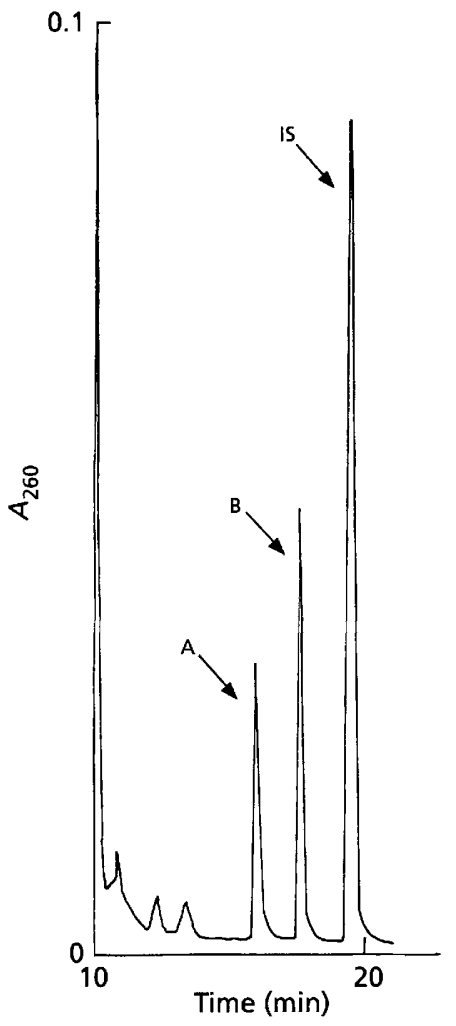

Fig. 2. HPLC chromatogram of the oxidation of decanoyl-CoA by a cell-free extract of $A$. niger (from triolein-grown cells). $A$, compound formed from the oxidation of decanoyl-COA; $B$, decanoyl-CoA; IS, internal standard (dodecanoyl-CoA). Incubation time: $60 \mathrm{~min}$. The initial part of the trace with peaks due to CoA, acetyl-CoA, etc., has been omitted for clarity. None of the peaks seen, apart from those indicated, could be identified with any likely CoA ester.

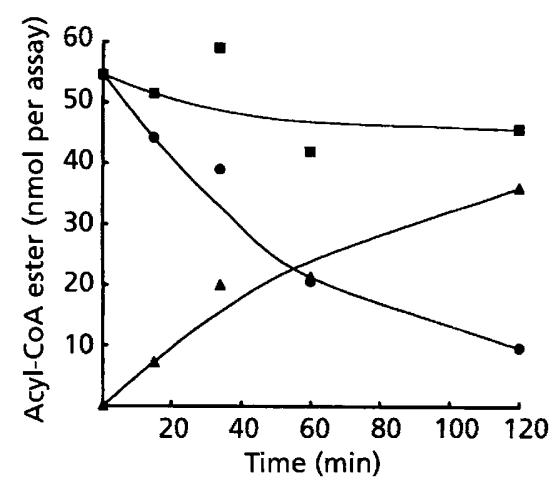

Fig. 3. Time-course of the formation of the product from decanoyl-CoA oxidation (compound A) by a cell-free extract of A. niger (from triolein-grown cells). O, Decanoyl-CoA; compound $A ; \mathbf{Q}$, total.

CoA decreased (Fig. 3). The experiment was repeated and the results were confirmed. The retention time of this compound identified it as octanoyl-CoA, which correlated well with the finding of $0.8 \mathrm{~mol}$ acetyl-CoA released per mol decanoyl-CoA consumed. With a $1 \mathrm{~h}$ incubation mixture in the absence of $\mathrm{NAD}^{+}$, no
Table 2. Enzyme activities in fractions $\left(\mathrm{S}_{16000}\right.$ and $\left.\mathrm{P}_{16000}\right)$ of $A$. niger cell homogenate

Mycelia were grown on glucose ( $2 \%$, YEPD) for $16 \mathrm{~h}$. A crude mitochondrial pellet was prepared as described in Methods, and was suspended in isolation buffer. Homogenate fractions were disrupted (by sonication) for enzyme assays. $S_{16000}$, $16000 \mathrm{~g}$ supernatant $\left(150 \mathrm{mg}\right.$ protein); $\mathrm{P}_{\mathbf{1 6 0 0 0}}, 16000 \mathrm{~g}$ pellet (20 mg protein).

\begin{tabular}{|c|c|c|c|c|}
\hline \multirow[t]{2}{*}{ Enzyme } & \multicolumn{4}{|c|}{$\begin{array}{l}\text { Enzyme activity [total U } \\
\left.\qquad\left(\mu \mathrm{mol} \min ^{-1}\right)\right]\end{array}$} \\
\hline & $S_{16000}$ & $(\%)$ & $P_{16000}$ & $(\%)$ \\
\hline Citrate synthase & $37 \cdot 5$ & (49) & 39 & $(51)$ \\
\hline Enoyl-CoA hydratase & 8 & $(50)$ & 8 & $(50)$ \\
\hline $\begin{array}{l}\text { 3-Hydroxyacyl-CoA } \\
\text { dehydrogenase }\end{array}$ & $0 \cdot 1$ & $(12 \cdot 5)$ & 0.7 & $\langle 87 \cdot 5\rangle$ \\
\hline 3-Ketoacyl-CoA thiolase & 5 & $(92 \cdot 6)$ & $0 \cdot 4$ & $(7 \cdot 4)$ \\
\hline Carnitine acetyltransferase & $5 \cdot 2$ & $(55)$ & $4 \cdot 3$ & $(45)$ \\
\hline
\end{tabular}

octanoyl-CoA or acetyl-CoA was formed, but instead, 3-hydroxydecanoyl-CoA and 2-decenoyl-CoA in the proportion of $10: 1$. Now 3-hydroxyacyl-CoA dehydrogenase was inoperative and there was accumulation of intermediates prior to the blocked step. Similar findings have been found by other workers with other systems (Broadway et al., 1992; Stanley \& Tubbs, 1974, 1975; Watmough et al., 1989). With decanoyl-CoA, $\mathrm{NAD}^{+}$ and $0.1 \mathrm{U}$ acyl-CoA oxidase included, a $20 \mathrm{~min}$ incubation produced dramatic change. The 10-fold increase in the decanoyl-CoA processing capacity gave rise in $5 \mathrm{~min}$ to $>95 \%$ loss of the initial $100 \mathrm{nmol}$ decanoylCoA substrate and formation of $40 \mathrm{nmol}$ hexanoylCoA, $18 \mathrm{nmol}$ 3-hydroxyoctanoyl-CoA or hexenoyl$\mathrm{CoA}$ and $30 \mathrm{nmol}$ octanoyl-CoA. After $20 \mathrm{~min}$ there appeared to be $95 \mathrm{nmol}$ butanoyl-CoA and most of the other intermediates had disappeared. This experiment confirmed that the limited $\beta$-oxidation activity of triolein-grown cell extracts was primarily due to the low activity of acyl-CoA dehydrogenase. It also showed that when the rate-limiting step for the overall process was changed, then intermediates other than the saturated CoA esters accumulated, at least temporarily.

\section{$\beta$-Oxidation enzymes in mitochondria}

Mitochondria were obtained from non-induced, glucose-grown cells by sand grinding and centrifugation. The mitochondria exhibited respiratory ratios $(\mathrm{P}: \mathrm{O})$ of $1.5-2.0$ on addition of $0.3 \mathrm{mM}$ ADP to assays measuring $\mathrm{O}_{2}$ uptake consequent upon sodium succinate $(10 \mathrm{mM})$ oxidation. Density-gradient centrifugation of a mitochondrial fraction on a Percoll gradient showed one sharp band of citrate synthase (mitochondrial marker) in the middle of the gradient and little activity in peripheral fractions. The distribution of $\beta$-oxidation enzymes, together with citrate synthase and carnitine acetyltransferase, is shown in Table 2 for supernatant and mitochondrial fractions of crude cell extract. About 
$50 \%$ of the original mitochondria were apparently preserved intact. The distribution of the $\beta$-oxidation enzymes was rather variable and reflected the contributions of the mitochondrial and microbody fractions. However, the low activity of 3-ketoacyl-CoA thiolase in the mitochondria seemed noteworthy. The experiment was repeated and the results were essentially the same. Kionka \& Kunau (1985) found only enoylCoA hydratase in mitochondria from sucrose-grown $N$. crassa.

Isolation of mitochondria was also attempted from triolein-grown cells $(0.25 \%, \mathrm{w} / \mathrm{v})$, but the results were less satisfactory. The cells were more difficult to extract and only $20 \%$ of the initial mitochondria remained intact, as judged by citrate synthase and carnitine acetyltransferase activities. The respiratory ratios $(\mathrm{P}: \mathrm{O})$ were 1.2-1.4 and density-gradient centrifugation of a mitochondrial fraction showed citrate synthase distributed throughout the gradient. Despite these deficiencies the distribution of the $\beta$-oxidation enzymes appeared much the same as indicated by the results of Table 2 .

\section{DISCUSSION}

The main objective of the present work was to test the hypothesis (Lawrence \& Hawke, 1968) that methyl ketone production from medium-chain-length fatty acids is primarily associated with $\beta$-oxidation. This view is widely held, but there is little direct experimental evidence to support it. An alternative scheme based on work with extracts of Penicillium decumbens was proposed (Yagi et al., 1991) involving formation of the secondary alcohol in the cell wall layer followed by oxidation to methyl ketone. We have reproduced observations of the type used to support the alternative mechanism, but we have been unable to reproduce the central requirement of cell-free extracts capable of producing methyl ketones from fatty acids.

Our studies showed that $\beta$-oxidation enzymes of $A$. niger were induced by growth on triolein with strong induction (400-fold) of acyl-CoA dehydrogenase. Electron microscopy also showed that large numbers of peroxisomes appeared over this period. However, the inability of extracts to produce 2-heptanone from octanoic acid showed that the specificity of $\beta$-oxidation enzymes cannot alone explain methyl ketone formation. Some additional factor(s) is also needed.

$\beta$-Oxidation experiments and HPLC analyses (Figs 2 and 3) showed that the capacity for $\beta$-oxidation of medium-chain-length fatty acids by extracts of induced cells was limited to one turn of the spiral. This limitation appeared to be entirely due to the rate-limiting activity or specificity of acyl-CoA dehydrogenase, because added acyl-CoA oxidase led to more extensive degradation and the appearance of a range of chain-shortened CoAesters. The rate-limiting behaviour of acyl-CoA dehydrogenase is often encountered with $\beta$-oxidation systems as, for example, in Corynebacterium 7E1C (Broadway et al., 1992) and mammalian liver mitochondria (Watmough et al., 1989). Peroxisomal $\beta$ - oxidation in rat liver was shown to be incomplete although the degree of chain shortening varied with the experimental conditions (Osmundsen et al., 1979; Lazarow, 1982; Bartlett et al., 1990). The present work is unusual in describing a $\beta$-oxidation system predisposed to give only one turn of the cycle with mediumchain-length fatty acids. The finding seems to offer at least a partial explanation of why, for example, whole cells produced only 2 -nonanone from decanoic acid and no 2-heptanone or 2-pentanone.

The results on $\beta$-oxidation do not provide the basis for a comprehensive explanation of methyl ketone formation from medium-chain-length fatty acids. Such an explanation could not be expected, in view of the inability of the extracts to synthesize these compounds. However, it is clear that octanoyl-CoA would be bound to accumulate from decanoate oxidation and if it was also the case that CoA supplies were limited, then a pool of 3-ketodecanoyl-CoA would form by equilibration through 3-ketoacyl-CoA thiolase with octanoyl-CoA and acetyl-CoA. Under these circumstances, deacylation of some 3-ketodecanoyl-CoA and decarboxylation of 3ketodecanoate to 2-nonanone can be envisaged. Lawrence \& Hawke (1968) suggested that methyl ketone formation is due to lack of free CoA and that deacylation of 3-ketoacyl-CoA allows CoASH to be recycled quickly to other parts of the cell. Also, Hatton \& Kinderlerer (1991) provided evidence that the rate of methyl ketone formation is increased when the cells are stressed by some form of nutritional stringency.

The results with isolated mitochondria raised the possibility that these organelles could be the source of methyl ketone synthesis because of low 3-ketoacyl-CoA thiolase activity and possibly also low concentrations of CoA. Some support for the idea also came from the finding that glucose-grown $A$. niger proved effective at producing 2-heptanone from a low concentration of octanoic acid $(1 \mathrm{mM})$. Such cells contained very few microbodies initially although the number increased quickly in a $4 \mathrm{~h}$ incubation. Against this proposal, however, was the finding that the mitochondria from either glucose- or triolein-grown cells showed no detectable activity for acyl-CoA dehydrogenase or carnitine acyltransferase. The latter was not a serious problem because Sherratt \& Spurway (1994) stated that medium-chain fatty acids can enter mitochondria. However, the lack of acyl-CoA dehydrogenase suggests that 3-ketoacyl-CoA esters could not accumulate in mitochondria unless there was an alternative route for supplying enoyl-CoA or 3-hydroxyacyl-CoA esters. The finding of high mitochondrial enoyl-CoA hydratase activity in both glucose- and triolein-grown cells (Table 2; see also Kionka \& Kunau, 1985, with N. crassa) suggests that the substrates for the enzyme might be available under some circumstances.

\section{ACKNOWLEDGEMENTS}

We are grateful to the Fundação para a Ciência e a Tecnologia (FCT), who provided financial support through the Portuguese research program 'Praxis XXI' 


\section{REFERENCES}

Bartlett, K., Watmough, N. J. \& Causey, A. G. (1988). Intermediates of $\beta$-oxidation. Biochem Soc Trans 16, 410-416.

Bartlett, K., Hovik, R., Eaton, S., Watmough, N. J. \& Osmundsen, $H$. (1990). Intermediates of peroxisomal $\beta$-oxidation; a study of the fatty acyl-CoA esters which accumulate during peroxisomal $\beta$ oxidation of $\left[\mathrm{U}-{ }^{14} \mathrm{C}\right]$ hexadecanoate. Biochem J 270, 175-180.

Binstock, J. F. \& Schulz, H. (1981). Fatty acid oxidation complex in Escherichia coli. Methods Enzymol 71, 403-411.

Bradford, M. M. (1976). A rapid and sensitive method for the quantitation of microgram quantities of protein utilising the principle of protein-dye binding. Anal Biochem 72, 248-254.

Broadway, N. M., Dickinson, F. M. \& Ratledge, C. (1992). Longchain acyl-CoA ester intermediates of $\beta$-oxidation of mono- and di-carboxylic fatty acids by extracts of Corynebacterium sp. strain 7E1C. Biochem J 285, 117-122.

Causey, A. G. \& Bartlett, K. (1986). The analysis of $C_{2}-C_{16}$ acylCoA esters by high-performance liquid chromatography. Biochem Soc Trans 14, 1175-1176.

Dommes, P., Dommes, V. \& Kunau, W.-H. (1983). $\beta$-Oxidation in Candida tropicalis - partial purification and biological function of an inducible 2,4-dienoyl Coenzyme-A reductase. $J$ Biol Chem 258, 10846-10852.

Graves, L. B., Armentrout, V. N. \& Maxwell, D. P. (1976). Distribution of glyoxylate-cycle enzymes between microbodies and mitochondria in Aspergillus tamarii. Planta 132, 143-148.

Hatton, P. V. \& Kinderlerer, J. L. (1991). Toxicity of medium chain fatty acids to Penicillium crustosum Thom and their detoxification to methyl ketones. J Appl Bacteriol 70, 401-407.

Ichihara, K. \& Shibasaki, Y. (1991). An enzyme-coupled assay for Acyl-CoA synthetase. J Lipid Res 32, 1709-1712.

Kionka, C. \& Kunau, W.-H. (1985). Inducible $\beta$-oxidation pathway in Neurospora crassa. J Bacteriol 161, 153-157.

Kunau, W.-H., Bühne, S., De La Garza, M., Kionka, K., Mateblowski, M., Schultz-Borchard, U. \& Thieringer, R. (1988). Comparative enzymology of $\beta$-oxidation. Biochem Soc Trans 16, 418-420.

Lambowitz, A. M., Smith, E. W. \& Slayman, C. W. (1972). Oxidative phosphorylation in Neurospora crassa mitochondria. Studies on wild type, poky, and chloramphenicol-induced wild type. J Biol Chem 247, 4859-4865.

Lawrence, R. C. \& Hawke, J. C. (1968). The oxidation of fatty acids by mycelium of Penicillium roqueforti. J Gen Microbiol 51, 289-302.

Lazarow, P. B. (1982). Rat liver peroxisomes catalyse the $\beta$ oxidation of fatty acids. J Biol Chem 253, 1522-1528.

Mannella, C. A. (1982). Structure of the outer mitochondrial membrane: ordered arrays of porelike subunits in outer-membrane fractions from Neurospora crassa mitochondria. $J$ Cell Biol 94, 680-687.
Osmundsen, H., Neat, C. E. \& Norum, K. R. (1979). Peroxisomal oxidation of long chain fatty acids. FEBS Lett 99, 292-296.

Parvin, R. (1969). Citrate synthase from yeast. Methods Enzymol 13, 16-19.

Pontecorvo, G., Roper, J. A., Hemmons, D. W., MacDonald, K. D. \& Bufton, A. W. (1953). The genetics of Aspergillus nidulans. Adv Genet 5, 141-238.

Ramsay, R. R. \& Tubbs, P. K. (1975). The mechanism of fatty acid uptake by heart mitochondria: an acylcarnitine-carnitine exchange. FEBS Lett 54, 21-25.

Seubert, W., Lamberts, I., Kramer, R. \& Ohly, B. (1968). On the mechanism of malonyl-CoA-independent fatty acid synthesis. I. The mechanism of elongation of long-chain fatty acids by acetylCoA. Biochim Biophys Acta 164, 498-517.

Sherratt, H. S. A. \& Spurway, T. D. (1994). Regulation of fatty acid oxidation in cells. Biochem Soc Trans 22, 423-427.

Simon, E. J. \& Shemin, D. (1953). The preparation of $S$-succinyl coenzyme A. J Am Chem Soc 75, 2520.

Stanley, K. K. \& Tubbs, P. K. (1974). The occurrence of intermediates in mitochondrial fatty acid oxidation. FEBS Lett 39 , 325-328.

Stanley, K. K. \& Tubbs, P. K. (1975). The role of intermediates in mitochondrial fatty acid oxidation. Biochem J 150, 77-88.

Thieringer, R. \& Kunau, W.-H. (1991). The $\beta$-oxidation system in catalase-free microbodies of the filamentous fungus Neurospora crassa. Purification of a multifunctional protein processing 2 enoyl-CoA hydratase, L-3-hydroxyacyl-CoA dehydrogenase and 3-hydroxyacyl-CoA epimerase activities. J Biol Chem 266, 13110-13117.

Watmough, N. J., Turnbull, D. M., Sherratt, H. S. A. \& Bartlett, K. (1989). Measurement of the acyl-CoA intermediates of $\beta$-oxidation by HPLC with on-line radiochemical and photodiodearray detection; application to the study of $\left[\mathrm{U}-{ }^{14} \mathrm{C}\right]$ hexadecanoate oxidation by intact rat liver mitochondria. Biochem $J \mathbf{2 6 2}$, 261-269.

Werner, W., Rey, H.-G. \& Wielinger, H. (1970). Über die Eigenshaften eine neuen Chromogens für die Blutzuckerbestimung nach der GOD/POD Methode. Z Anal Chem 252, 224-228.

Yagi, T., Kawaguchi, M., Hatano, T., Fukui, F. \& Fukui, S. (1990). Screening of methylalkylketone-accumulating fungi from type culture strain. J Ferment Bioeng 70, 94-99.

Yagi, T., Hatano, A., Hatano, T., Fukui, F. \& Fukui, S. (1991). A novel enzyme system : the n-alkane-2-one-forming enzyme system in Penicillium decumbens IFO-7091. J Ferment Bioeng 71, 439-441.

Received 19 June 1998; revised 17 August 1998; accepted 17 September 1998. 